\title{
Clinico-pathological profile of paediatric patients with thalassemia major
}

\author{
Sharma S. ${ }^{1}$, Tikkas R. ${ }^{2 *}$, Uikey R. ${ }^{3}$, Kumar V. ${ }^{4}$ \\ DOI: https://doi.org/10.17511/ijpr.2020.i02.01
}

${ }^{1}$ Shweta Sharma, Associate Professor, Department of Pediatrics, Gandhi Medical College, Bhopal, Madhya Pradesh, India.

2* R. Tikkas, Professor, Department of Pediatrics, Gandhi Medical College, Bhopal, Madhya Pradesh, India.

3 Rajni Uikey, Postgraduate, Department of Pediatrics, Gandhi Medical College, Bhopal, Madhya Pradesh, India.

4 Vinay Kumar, Postgraduate, Department of Pediatrics, Gandhi Medical College, Bhopal, Madhya Pradesh, India.

Background: The average prevalence of beta-thalassemia major is 3-4\% which translates to $35-45$ million carriers. Repeated use of blood transfusion in these patients causes significant morbidity and associated adverse effects. Aims and Objective: To study the clinical profile and laboratory parameters of Thalassemia major patients between the age group 1-14 years. Methodology: A Descriptive Observational study was done on 101 children of Beta-thalassemia major patients aged between 1-14 yr being regularly transfused at the Department of Pediatrics, Kamla Nehru Hospital, Gandhi Medical College, Bhopal, during the study period of March 2017 to Feb 2018. This included history, anthropometry, clinical examinations (general and systemic examinations) and laboratory Investigations including serum ferritin. RESULT: result showed that $42 \%$ patients were found to be underweight, $26.73 \%$ were short stature, $31.68 \%$ were hypocalcemic, $44.5 \%$ had low serum alkaline phosphatase. Transfusion frequency and serum ferritin were less in 1-5 years. A significant correlation was observed between the size of the spleen and the level of ferritin. CONCLUSION: Hereby it can be concluded that early diagnosis of the disease and early institution of chelation therapy can improve the life expectancy of the Beta-thalassemia patients.

Keywords: Beta-thalassemia, Ferritin, Splenomegaly, Chelation, Transfusion

Corresponding Author

R. Tikkas, Professor, Department of Pediatrics, Gandhi Medical College, Bhopal, Madhya Pradesh, India.

Email: raj_tikkas@rediffmail.com
How to Cite this Article

To Browse

Sharma S, Tikkas R, Uikey R, Kumar V. Clinicopathological profile of paediatric patients with thalassemia major. Pediatric Rev Int J Pediatr Res. 2020;7(2):49-55.

Available From

https://pediatrics.medresearch.in/index.php/ijpr/arti cle/view/573

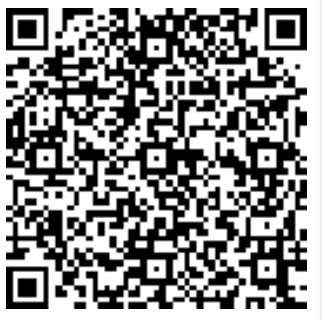

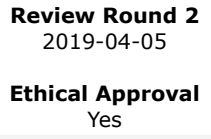

\section{Review Round 3}

Accepted 2019-04-09

Note 


\section{Introduction}

Thalassemia refers to a group of disorders of globin chain production in which there is an imbalance between the a-globin and $\beta$-globin chains, which results in a relative excess of the a-globin chain. $\beta$ Thalassemia major refers to the severe form of $\beta$ Thalassemia which requires early blood transfusion therapy and often is homozygous for $\beta$ mutations.

According to WHO $3.3 \%$ is the average frequency of Thalassemia carriers in India. In the state of Madhya Pradesh high prevalence of $\beta$-Thalassemia trait $(20.70 \%)$ is observed [1]. Over the past three decades, regular blood transfusions and iron chelation have dramatically improved the quality of life and transformed Thalassemia major from a rapidly fatal disease in early childhood to a chronic disease compatible with prolonged life. Today life expectancy varies between 25-55 years, depending on the compliance with medical treatment.

Endocrine functions of Thalassemic children progressively decline with age secondary to hemosiderosis and nutritional deficiencies, resulting in multiple endocrinopathies like hypothyroidism, growth hormone deficiency, delayed puberty, diabetes mellitus and osteoporosis. So, all these children require regular monitoring of endocrine functions after 5 years of age, and regular monitoring of height, weight semi-annually.

\section{Aims and Objectives}

To study the clinical profile and laboratory parameters of Thalassemia major patients between age group 1-14 years.

\section{Material and Method}

Type of study: It was a Descriptive- Observational study carried out in the Department of Pediatric Medicine, Kamla Nehru Hospital in collaboration with the Department of Biochemistry, Department of Pathology and Department of Microbiology of GMC, Bhopal, (M.P). Within 12 months from March 2017 to February 2018.

Sample collection and methods: This study was conducted on 101 children with $\beta$-Thalassemia major patients aged between 1-14 year being regularly transfused at the Department of Pediatric Medicine, Kamla Nehru Hospital, Gandhi Medical College Bhopal, (M.P.).
A preformed and pre-checked proforma was used for data collection that included personal information, data regarding the number of transfusions and pre-transfusion haemoglobin and serum ferritin, at what dose of chelators they were with clinical examination finding and laboratory investigation reports.

The current study has collected the data by using predesigned and pretested proforma which was fulfilling the objective of the study. A unique ID was given to each patient. A detailed history of all the registered patients including personal data, history of consanguineous marriage, nutrition, frequency of transfusion, use of iron-chelating agent including dose, duration and compliance). A thorough physical examination was performed including anthropometry, general examination and systemic examination and was recorded in the proforma.

Following anthropometric measurements were recorded:

Weight, Length/Height, and mid-upper-arm circumference using standard methods. Anthropometry details (weight, height and midupper arm circumference) were reviewed as per WHO criteria and patients were classified accordingly in SAM and MAM category.

Transfusion index is calculated by the formula blood volume received in $\mathrm{ml} / \mathrm{kg} /$ month.

The serum ferritin level was measured in all Thalassemic patients. Iron chelating agents were advised to all patients with serum ferritin level above $1000 \mathrm{ng} / \mathrm{ml}$. Haemoglobin was measured before transfusion by Sahli's method. Blood group cross-matching was done by blood typing. Standard references were used.

Data regarding various clinical and laboratory parameters were recorded and tabulated and presented as frequency, percentage and mean.

\section{Inclusion criteria}

All the diagnosed $\beta$-Thalassemia major patients between the age group of 1 to 14 years attending the Department of Pediatric medicine, Kamla Nehru Hospital, Gandhi Medical College, Bhopal, (M.P.).

\section{Exclusion criteria}

01. Patients are less than one year and more than 14 years of age group.

02. Children having multiple congenital anomalies along with Thalassemia major. 
03. Coexisting cardiac or pulmonary disease.

04. Chronic haemolytic anaemia, other than $\beta$ Thalassemia major.

05. Thalassemia minor

06. Beta -thalassemia with any other haemolytic anaemia

Ethical permission: The study was performed after obtaining proper ethical clearance from the respective ethical committee.

Statistical analysis: The data collected were analysed with Graph Ped statistical software version 7.0. Continuous variables were presented as mean for parametric data. The student t test was applied for the calculation of statistical significance whenever the data followed normative distribution.

Nominal categorical data between the groups have been compared using Chi-square test or Fisher's exact test as appropriate. $\mathrm{P}<0.05$ was taken to indicate a statistically significant difference. Correlational analysis was done by calculating the correlation coefficient.

\section{Result}

Table 1 represented the distribution of cases according to sex. $66.34 \%$ of cases were males, whereas $33.66 \%$ of cases were females.

Table-1: Distribution of cases according to sex.

\begin{tabular}{|l|l|l|}
\hline \multicolumn{1}{|c|}{ Sex } & \multicolumn{1}{c|}{ No of cases $(\mathbf{N}=\mathbf{1 0 1})$} & \multicolumn{1}{c|}{ Percent } \\
\hline Females & 34 & 33.66 \\
\hline Males & 67 & 66.34 \\
\hline
\end{tabular}

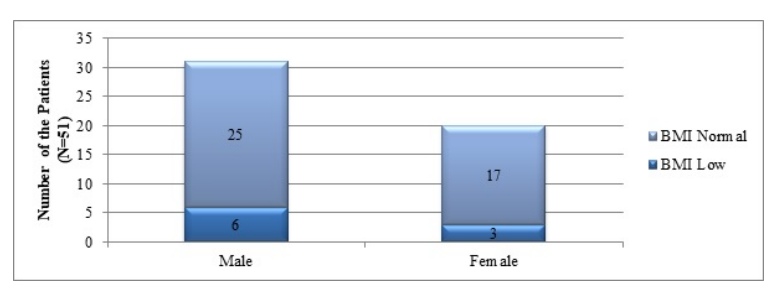

Fig-1 Showing distribution of patients according to Body Mass Index (BMI) $(n=51)$.

Table-2: Showing distribution of patients according to Height for age $(\mathbf{n = 1 0 1})$.

\begin{tabular}{|l|l|l|}
\hline & \multicolumn{1}{|c|}{ Short stature (below 3rd centile) } & \multicolumn{1}{|c|}{ Normal stature } \\
\hline Male & $19(38 \%)$ & $48(47.52 \%)$ \\
\hline Female & $08(16 \%)$ & $26(25.74 \%)$ \\
\hline Total & $27(26.73 \%)$ & $74(73.26 \%)$ \\
\hline
\end{tabular}

Fig-02: Serum Calcium values in Thalassemic patients(mg/dl).

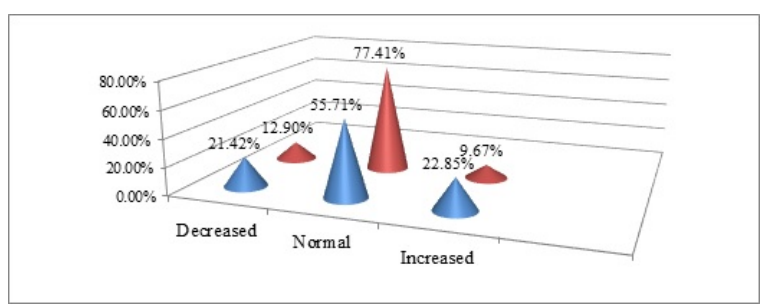

Table-3 Serum Phosphorus values $(\mathrm{mg} / \mathrm{dl})$.

\begin{tabular}{|l|l|l|l|c|}
\hline Age (Years) & \multicolumn{1}{|c|}{ Decreased } & \multicolumn{1}{|c|}{ Normal } & \multicolumn{1}{|c|}{ Increased } & Total \\
\hline $1-3$ & $15(60 \%)$ & $04(16 \%)$ & $06(24 \%)$ & $25(24.75 \%)$ \\
\hline $4-11$ & $23(36.50 \%)$ & $15(23.80 \%)$ & $25(39.68 \%)$ & $63(62.37 \%)$ \\
\hline $12-14$ & $01(7.69 \%)$ & $07(53.84 \%)$ & $05(38.46 \%)$ & $13(12.87 \%)$ \\
\hline Total & 39 & 26 & 35 & 101 \\
\hline
\end{tabular}

Table-4: Serum Alkaline Phosphatase (I/U).

\begin{tabular}{|l|l|l|l|}
\hline \multicolumn{1}{|c|}{ Age $(\mathrm{Yr})$} & \multicolumn{1}{c|}{ Normal } & \multicolumn{1}{c|}{ Increased } & \multicolumn{1}{c|}{ Total } \\
\hline$<8$ & $43(61.42 \%)$ & $27(38.57 \%)$ & $70(69.30 \%)$ \\
\hline$>8$ & $07(22.58 \%)$ & $24(77.41 \%)$ & $31(30.69 \%)$ \\
\hline Total & 50 & 51 & 101 \\
\hline
\end{tabular}

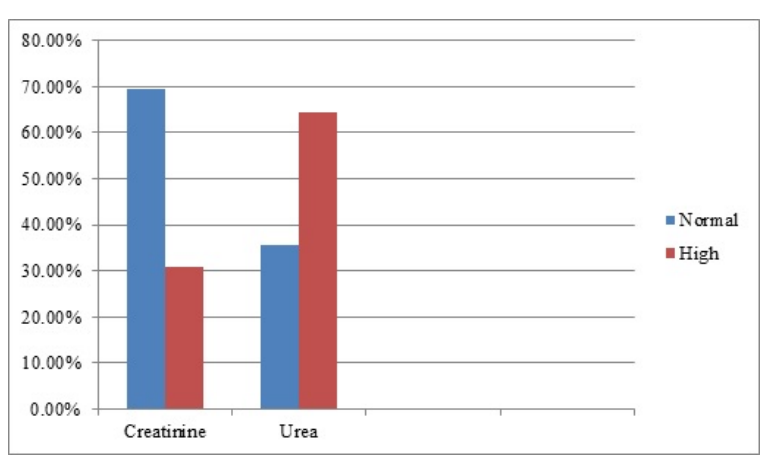

Fig-3: Renal functions in thalassemia major patients(mg/dL).

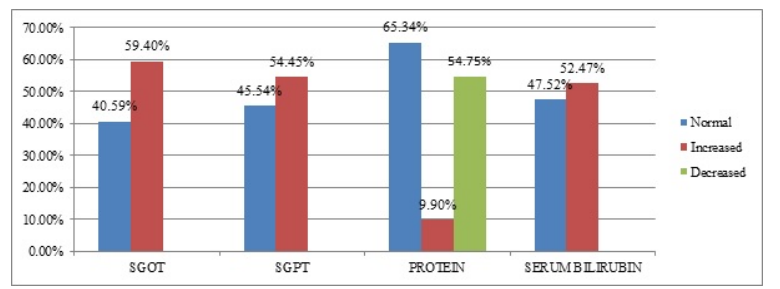

Fig-4: Liver Enzymes in Thalassemic patients(U/L).

Table-5: Correlation of liver function test, renal function test with serum ferritin.

\begin{tabular}{|l|l|l|}
\hline Dependent Indices & \multicolumn{1}{|c|}{$\begin{array}{c}\text { Correlation to Serum ferritin (R- } \\
\text { square) }\end{array}$} & $p$-Value \\
\hline SGOT & 0.01056 & $p>0.05$ \\
\hline SGPT & 0.003635 & $p>0.05$ \\
\hline Serum Bilirubin Total & 0.0338 & $p>0.05$ \\
\hline $\begin{array}{l}\text { Serum Bilirubin } \\
\text { Direct }\end{array}$ & 0.000187 & $p>0.05$ \\
\hline
\end{tabular}


Sharma S. et al: Clinico-pathological profile of paediatric patients

\begin{tabular}{|l|l|l|}
\hline Total Serum Protein & 0.01235 & $p>0.05$ \\
\hline Serum Albumin & 0.01714 & $p>0.05$ \\
\hline Serum Urea & 0.0137 & $p>0.05$ \\
\hline Serum Creatinine & 0.006981 & $p>0.05$ \\
\hline
\end{tabular}

Table-06: Showing correlation of Hepatomegaly with transfusion index and different range of serum ferritin in all three groups.

\begin{tabular}{|c|c|c|}
\hline Age Group & S. Ferritin & Transfusion Index \\
\hline \multirow[t]{12}{*}{$1-5$ years $(N=50)$} & $<500-1000$ & $r=-0.899$ \\
\hline & $(n=4 / 10)$ & $p=0.0004$ \\
\hline & $8.3 \pm 5.3 \mathrm{~cm}$ & $(53.7 \pm 125.4)$ \\
\hline & 1001-1500 & $r=-0.164$ \\
\hline & $(n=13 / 21)$ & $p=0.479$ \\
\hline & $8.67 \pm 2.65 \mathrm{~cm}$ & $(15.4 \pm 24.12)$ \\
\hline & 1501-2000 & $r=0.308$ \\
\hline & $(n=6 / 7)$ & $p=0.502$ \\
\hline & $9.36 \pm 2.63 \mathrm{~cm}$ & $(15.95 \pm 6.38)$ \\
\hline & $>2000$ & $r=-0.235$ \\
\hline & $(n=10 / 12)$ & $p=0.461$ \\
\hline & $9.38 \pm 1.83 \mathrm{~cm}$ & $(15.13 \pm 9.01)$ \\
\hline \multirow[t]{12}{*}{$6-10$ years $(N=33)$} & $\mid<500-1000$ & $r=-0.535$ \\
\hline & $(n=7 / 9)$ & $p=0.138$ \\
\hline & $8.33 \pm 2.12 \mathrm{~cm}$ & $(56.14 \pm 96.2)$ \\
\hline & $1001-1500$ & $r=-0.180$ \\
\hline & $(n=3 / 3)$ & $\mathrm{p}=0.885$ \\
\hline & $9.91 \pm 1.27 \mathrm{~cm}$ & $(24.14 \pm 5.79)$ \\
\hline & $1501-2000$ & $r=-0.091$ \\
\hline & $(n=3 / 3)$ & $p=0.942$ \\
\hline & $11.17 \pm 4.54 \mathrm{~cm}$ & $(150.0 \pm 203.7)$ \\
\hline & |>2000 & $r=-0.163$ \\
\hline & $(n=16 / 18)$ & $p=0.519$ \\
\hline & $10.47 \pm 2.71 \mathrm{~cm}$ & $(43.46 \pm 72.57)$ \\
\hline \multirow[t]{12}{*}{$11-14$ years $(N=18)$} & $\mid<500-1000$ & $r=N A$ \\
\hline & $(n=2 / 2)$ & $p=N A$ \\
\hline & $8.5 \pm 0.7 \mathrm{~cm}$ & $(32.5 \pm 10.61)$ \\
\hline & 1001-1500 & $r=-0.821$ \\
\hline & $(n=3 / 4)$ & $p=0.179$ \\
\hline & $9.75 \pm 2.99 \mathrm{~cm}$ & $(25.0 \pm 7.94)$ \\
\hline & $1501-2000$ & $r=0.492$ \\
\hline & $(n=4 / 5)$ & $p=0.395$ \\
\hline & $8.8 \pm 2.8 \mathrm{~cm}$ & $(32.33 \pm 5.07)$ \\
\hline & |>2000 & $r=-0.479$ \\
\hline & $(n=6 / 7)$ & $p=0.276$ \\
\hline & $8.86 \pm 3.39 \mathrm{~cm}$ & $(113.1 \pm 149.4)$ \\
\hline
\end{tabular}

Table-7: Showing correlation of different grades of splenomegaly with serum ferritin and transfusion index.

\begin{tabular}{|c|c|c|c|c|c|}
\hline $\begin{array}{c}\text { Spleen } \\
\text { Size }\end{array}$ & $\begin{array}{c}\mathbf{1 - 5} \\
\text { years }\end{array}$ & $\begin{array}{c}\mathbf{6 - 1 0} \\
\text { years }\end{array}$ & $\begin{array}{c}\mathbf{1 1 - 1 4} \\
\text { years }\end{array}$ & $\begin{array}{c}\text { Serum } \\
\text { Ferritin }\end{array}$ & $\begin{array}{c}\text { Transfusion } \\
\text { Index }\end{array}$ \\
\hline$<2 \mathrm{~cm}$ & 03 & 02 & 00 & $\mathrm{r}=-0.1109$ & $\mathrm{r}=-0.1651$ \\
\hline
\end{tabular}

\begin{tabular}{|l|l|l|l|l|l|}
\hline & & & & $\begin{array}{l}p=0.6938 \\
(2517 \pm 2274)\end{array}$ & $\begin{array}{l}p=0.5565 \\
(41.11 \pm 86.14)\end{array}$ \\
\hline $2-7 \mathrm{~cm}$ & 31 & 16 & 05 & $\begin{array}{l}r=-0.1242 \\
p=0.3805 \\
(1966 \pm 1574)\end{array}$ & $\begin{array}{l}\mathrm{r}=-0.04663 \\
p=0.7427 \\
(37.85 \pm 78.44)\end{array}$ \\
\hline$>7 \mathrm{~cm}$ & 11 & 15 & 08 & $\begin{array}{l}r=0.4222 \\
p=0.0129 \\
(2365 \pm 1949)\end{array}$ & $\begin{array}{l}\mathrm{R}=0.09043 \\
p=0.6110 \\
(44.05 \pm 81.86)\end{array}$ \\
\hline
\end{tabular}

\section{Discussion}

Children with $\beta$-Thalassemia major usually demonstrate no symptoms until about 2-3 months of age, when beta chains are needed to pair with alpha chains to form $\mathrm{HbA}$, since gamma chains production is turned off. However, in some cases, the condition may not be recognized until 3-5 years of age due to delay in the cessation of $\mathrm{HbF}$ production.

In the present study, at the time of enrolment, out of total 101 cases, 50 patients (49.50\%) were between $1-5$ years, 33 patients $(32.67 \%)$ were between $6-10$ years and 18 patients (17.82\%) were between 11-14 years. $\beta$-Thalassemia major affects both male and female equally but gender status in the present study shows male predominance with 67 male $(66.34 \%)$ and $34(33.66 \%)$ female $[2,3]$.

In the present study, Icterus was found to be present in $50 \%$ of cases. All the cases of this study had a normal feature which is commonly found in Thalassemic children like bony abnormalities, frontal bossing, prominent facial bones and dental malocclusion in the form of haemolytic facies were present. Oedema which can be a manifestation of both severe anaemia as well as SAM was found to be present in 11 cases [4].

In the present study, 51 patients were between the age of 6 to 14 years. Among them 6 males $(11.76 \%)$ and 3 females (5.88\%) were underweight which accounts for $17.64 \%$ of total cases as per WHO BMI charts, while 25 cases $(49.01 \%)$ of males and 17 cases (33.33\%) of females were having normal BMI. None of them was found to overweight. In the present study, there were 27 (26.73\%) patients who have been found short stature on the growth chart, out of which 19 cases (38\%) were boys and 08 cases (16\%) were girls which showed that, short stature was more in boys as compared to girls. The current study had a lower percentage of short stature as compared to Quaish Abdullal Salehe et al study in the year 2015, in which, $79 \%$ of the $\beta$-thalassemia patients had short stature $[2,5]$. 
In patients with $\beta$-thalassemia, low bone marrow density and fractures occur frequently and independently of the particular syndrome. In less than 08 years, $16(22.85 \%)$ cases had high i.e. hypercalcemia, $15(21.42 \%)$ cases had low i.e. hypocalcemia and $39(55.71 \%)$ cases were having normal levels of serum calcium. In greater than 08 years, $03(9.67 \%)$ cases had hypercalcemia, 04 (12.90\%) cases had hypocalcemia and $24(23.76 \%)$ cases had a normal level of serum calcium. This showed that thalassemic patients who were less than 08 years of age were more hypercalcemic as compared to patients more than 08 years of age. Similarly, hypocalcemia was seen more in thalassemic patients below 08 years of age.

In 1-3 years, cases, 15 (60\%) had low, 06 (24\%) had high and $04(16 \%)$ had a normal level of serum phosphorus. In 4 -11years, 23 (36.50\%) cases had low, $25(39.68 \%)$ cases had high and $15(23.80 \%)$ cases had normal serum phosphorus levels. In 1214 years, the only single case had hypophosphatemia, $05(38.46 \%)$ cases had high and $07(53.84 \%)$ cases had a normal level of Serum Phosphorus $[6,7,8,9]$.

The present study found 39 cases to have hypophosphatemia which account for $38.61 \%$, which may be due to renal function derangements and abnormality of bone marrow turnover $[10,11]$.

Renal profile of the patients showed almost $1 / 3$ rd cases $31(30.69 \%)$ case had high levels of creatinine, rest were having normal levels. Serum urea was high in 65(64.35\%) cases $[12,13,14,15,16]$. Though most of the urea and creatinine were only mildly elevated which may be due to chelator therapy in the higher age group.

In the present study, 50 patients of 1 to 5 years of age, $33(66 \%)$ patients showed hepatomegaly with the mean liver span of $8.86 \pm 3.14 \mathrm{~cm}$. and mean serum ferritin $1584 \pm 1116$. There was a positive correlation with serum ferritin concentration, transfusion index with respective correlation coefficients $(r)$ of $0.167,0.1552$ and 0.478 . Correlation of hepatomegaly with Transfusion index $(p<0.0001)$ and was statistically significant. Mean serum ferritin found in 06 to 10 years age group was $2976+/-2211$ and was also having $p$ value 0.026 .

In the present study, liver, span in patients of 1-5 years of age group was correlated significantly in serum ferritin levels less than $1000 \mathrm{ng} / \mathrm{ml}$ with transfusion index $(p=0.0004)$ [17].

\section{Conclusion}

There is a direct adverse impact of increasing serum ferritin values and transfusion index on anthropometric, clinical parameters and the biochemical parameters.

\section{What does the study add to the existing knowledge?}

Early estimation of serum ferritin and early institution of chelation therapy will have a better quality of life and can prevent complications in betathalassemia major patients.

\section{Author's contributions}

Dr. Shweta Sharma: Concept, study design

Dr. R. Tikkas: Manuscript preparation

Dr. Rajni Uikey: Data analysis

Dr. Vinay Kumar: Data analysis

\section{Reference}

01. Thakur S, Sharma R, Sharada R. Incidence of Thalassemia and Sickle Cell Disease in Chhattisgarh, Central India- Using Hardy-Weinberg Equations. J Mol Gen Med. 2014;9;155. doi: 10.4172/17470862.1000155 [Crossref][PubMed][Google Scholar]

02. Al-Salehe QAA, Al-Awady MS, Abbass SK. Growth Retardation In B-Thalassemia Major. Iraqi PG Med J. 2015;14(2). [Crossref][PubMed][Google Scholar]

03. Shah N, Mishra A, Chauhan D, Vora C, Shah NR. Study on effectiveness of transfusion program in thalassemia major patients receiving multiple blood transfusions at a transfusion centre in Western India. Asian J Transfus Sci. 2010;4(2)94-98. Available from: [Article][Crossref][PubMed][Google Scholar]

04. Hassan MY, Max J. Coppes- emedicine. Medscape. Aug 23, 2017. Available from [Article] [Crossref][PubMed][Google Scholar]

05. Ali S, Jahan S. Growth Failure in $\beta$-Thalassemia major Patients Undergoing Repeated Transfusions. JIIMC. 2016;11(3)120-124. [Crossref][PubMed] [Google Scholar] 
06. El-Nashar M, Mortagy AK, El-Beblawy NM, ElGohary E, Kamel IM, Rashad M, et al. Parathyroid hormone in pediatric patients with $\beta$-thalassemia major and its relation to bone mineral density- a case control study. Egypt J Med Human Genet. 2017;18(1)75-78.

doi: 10.1016/j.ejmhg.2016.03.004 [Crossref][PubMed] [Google Scholar]

07. Goyal M, Abrol P, Lal H. Parathyroid and Calcium Status in Patients with Thalassemia. Indian J Clin Biochem. 2010;25(4)385-387. doi: 10.1007\%2Fs12291-010-0071-5 [Crossref] [PubMed][Google Scholar]

08. Vogiatzi MG, Autio KA, Mait JE, Schneider R, Lesser $M$, Giardina PJ. Low bone mineral density in adolescents with $\beta$-thalassemia. Annals New York Acad Sci. 2005;1054(1)462-466. doi: 10.1196/annals.1345.063 [Crossref][PubMed] [Google Scholar]

09. Soliman A, Sanctis VD, Yassin M. Vitamin D Status in Thalassemia Major- an Update. Mediterr J Hematol Infect Dis. 2013;5(1)e2013057. doi: 10.4084\%2FMJHID.2013.057 [Crossref][PubMed] [Google Scholar]

10. Teli AB, Deori R, Saikia SP, Pathak K, Panyang R, Rajkakati R. $\beta$-Thalassaemia and its Co-existence with Haemoglobin $\mathrm{E}$ and Haemoglobin $\mathrm{S}$ in Upper Assam Region of North Eastern India- A Hospital Based Study. J Clin Diagn Res. 2016;10(4)GC01GC04. doi: 10.7860/JCDR/2016/16265.7675 [Crossref][PubMed][Google Scholar]

11. Sultan S, Irfan SM, Ahmed SI. Biochemical Markers of Bone Turnover in Patients with $\beta$ Thalassemia Major- A Single Center Study from Southern Pakistan. Advan Hematol. 2016. doi: 10.1155/2016/5437609 [Crossref][PubMed][Google Scholar]

12. Smolkin V, Halevy R, Levin C, Mines M, Sakran $W$, Ilia $K$, et al. Renal function in children with betathalassemia major and thalassemia intermedia. Pediatr Nephrol. 2008;23(10)1847-1851. doi: 10.1007/s00467-008-0897-8 [Crossref][PubMed] [Google Scholar]

13. Jalali A, Khalilian $H$, Ahmadzadeh A, Sarvestani $S$, Rahim F, Zandian $K$, et al. Renal function in transfusion dependent pediatric beta-thalassemia major patients. Hematol. 2011;16(4)249-254. doi: 10.1179/102453311X12953015767662 [Crossref] [PubMed][Google Scholar]
14. Hamed EA, ElMelegy NT. Renal functions in pediatric patients with beta-thalassemia majorrelation to chelation therapy- original prospective study. Italian J Pediatr. 2010;36;39. doi: 10.1186/1824-7288-36-39 [Crossref][PubMed] [Google Scholar]

15. Quinn CT, Johnson VL, Kim HY, Trachtenberg F, Vogiatzi MG, Kwiatkowski JL, et al. Renal dysfunction in patients with thalassaemia. $\mathrm{Br} \mathrm{J}$ Haematol. 2011;153(1)111-117. doi: 10.1111\%2Fj.1365-2141.2010.08477.x [Crossref] [PubMed][Google Scholar]

16. Lai ME, Spiga A, Vacquer S, Carta MP, Corrias C, Ponticelli C. Renal function in patients with $\beta$ thalassaemia major- a long-term follow-up study. Nephrol Dial Transplant. 2012;27(9)3547-3551. doi: 10.1093/ndt/gfs169 [Crossref][PubMed][Google Scholar]

17. Mishra AK, Tiwari A. Iron Overload In Beta Thalassaemia Major And Intermedia Patients. Maedica- J Clinic Med. 2013;8(4)328-332. [Crossref][PubMed][Google Scholar] 